\title{
A REVIEW OF GLOBAL SCENARIO OF BIODIESEL, SOURCES AND SLUDGE PALM OIL WASTE FOR THE BIODIESEL PRODUCTION
}

\author{
Manjunath R ${ }^{1}$, Archna ${ }^{2}$ \\ ${ }^{1}$ Sir M Visvesvaraya Institute of Technology, Biotechnology Department, Bangalore \\ ${ }^{2}$ M.S.Ramaiah Institute of Technology, Department Of Chemical Engineering, Bangalore
}

\begin{abstract}
The uncontrolled usage of fossil fuel and its by-products has largely contributed to global warming which is by far irreversible; these non-renewable reserves if exhausted might have a major impact on human development. This urges the need of discovering a sustainable renewable energy source which could potentially replace the fossil fuel in future, this is also the main focus researchers working on field of energy. A more sustainable biodiesel, which also is biodegradable and a clean energy has drawn a significant amount of attention and interest across the globe in recent years. Steady raise in the price of petroleum products and importantly the environmental concerns, highlighted the need of alternative fuels. Biodiesel primarily consists of Fatty Acid Methyl Esters (FAME), which are derived through transesterification of various sources such as vegetable oils, animal fat etc. In addition, the recycled oil from the food industry when processed with a suitable catalyst along with methanol produces mono alkyl esters, which are further segregated and purified. Bio-diesel can be produced through many techniques including acid \& base catalysis, enzymatic conversion, solid catalysis, non-catalytic conversion and super-critical methanolysis. Multiple factors such as, amount of alcohol, catalysts and reaction temperature, reaction time and FFA and water content of oils or fats impact the transesterification reaction. The multiple advantages of Biodiesel include safety, non-toxicity and biodegradable in comparison with petroleum based products, thus justifying its title as "Green fuel". The reduced polluting ability of Biofuels is due to the fact that they are oxygenated and are relatively free of sulfur and other aromatic compounds, thus being a effective fuel with reduced emission of Sulfuric oxides, Carbon monoxide, residual hydrocarbons and particulate matter. Thus no engine modification is required with the prior blending proportion with normal petroleum diesel. The major physicochemical properties are similar between biodiesel and the petroleum fuel. The present review made an attempt to cover the scenario of worldwide concerned towards biodiesel production, its scope and need, various sources adopted for biodiesel preparation, the various catalysts, reaction condition adopted, maintained during production of biodiesel and its fuel properties (depends on Free Fatty Acid profile of the feedstock) and an exclusive role of Sludge Palm Oil (SPO) form palm oil processing industries, a cost effective feedstock for biodiesel preparation.
\end{abstract}

Keywords:-FAME (Fatty Acid Methyl Esters), FFA (Free Fatty Acid), Sludge Palm Oil (SPO) $* * *$

\section{INTRODUCTION}

The life on earth needs energy to sustain and in modern world energy drives the economic growth. The closeness in physicochemical properties of biofuel to petroleum based products has resulted in increasing interest in liquid biofuel (Abdoli et al.,2014). The biofuels are mostly derived from vegetable sources. Biodiesel has been majorly produced from Rapeseed, Soybean, Sunflower, Coconut and Palm oils. However, in order to produce quality biofuel, these oils should be highly refined, thus shooting up the cost. Also, since most of these oils are edible oils, there is a high probability of rising food vs fuel debate. To avoid this plant oils derived from Non-edible sources such as Jatropha curcas and Castor beans stand as better alternatives for the before mentioned sources along with animal fat (Aldo et al.,2012)

The major benefit of Biodiesel is the reduced greenhouse gas emissions. Per earlier studies, the blends of biodiesel have reduced $\mathrm{CO}$ emission by about $50 \%$ and $\mathrm{CO} 2$ emissions by about $78 \%$, which are major green houses gases responsible for global warming. Additionally, usage of biodiesel which non-toxic and biodegradable, effectively reduces the quantity of fossil fuels being used (Angel et al.2012). $86 \%$ of global energy consumption and essentially most of energy utilized in transport and related sectors is provided by petroleum based products. The production of biofuels has been strongly backed by European Union (EU), which foresees that with increasing sources of fuel, reduction in greenhouse gases via de-carbonization of transportation fuels, strengthening the rural economy by providing increased earning opportunities, a long term plan to effectively replace fossil fuels and combat more serious issue of global warming and its ill effects. Biofuels such as biodiesel and bioethanol are extensively used in countries such as Austria, Australia, Germany, Italy and United States of America (Atadashi et al 2011). The reserves of fossil fuel are depleting because of uncontrolled usage, raising demands for petroleum based products from all over the world and uncertainty is supposed to be considered to motivate multiple initiatives in pursuit of an effective alternative energy source, which can replace fossil fuels supplement or search for alternative fuel (Singh et al., 2010). 
In connection to Atadashi et al.,(2011), A.Anitha et al.,(2010) also reported that petroleum based fuels majorly emit harmful emissions like Carbon dioxide, Carbon Monoxide and other Hydrocarbons, Particulate matters which is a threatening call to the environment necessitated an alternative fuel, that is biodegradable, renewable and readily available, carbon neutral transport fuel with clean burning capability. Fuels of biological origin (biodiesel) offer a potentially very interesting alternative to conventional diesel regarding reduction in harmful emissions in addition to its cost, engine wear, and availability. Though biodiesel seemingly is a potential replacement of diesel, the higher production costs and demand for edible oil for human needs will restrain edible oil from being used extensively for the production of biodiesel. Hence, it would not be awry to predict that nonedible oils such as waste vegetable oils, animal fats, waste sludge Palm oil, poultry wastes and slaughter house could act as a source of substitute source for the production of biodiesel. Identifying alternative cost effective sources for biodiesel production is the need of the day, given the fact that majority of countries in the world are yet dependent on fossil fuel for transportation and production of electricity. The increasing cost of fossil fuel necessitates the need to explore a novel source of energy which is economical as well as renewable (Ding et al.). The term biodiesel was coined by Canakci et al., (2001), which is an effective substitution to fuel used in diesel engines without any considerable alterations. By adopting this alternative energy fuel any country's current economic and energy scenario can transform into the era of economic bloom and prosperity of society can be achieved. (Divya Bajpai et al.,2006). The biodegradability of biofuel makes it eco-friendly which exhibits great potential and replacement for fossil fuels. Considering all these facts of concerned worldwide scenario towards biodiesel requirement a survey was performed by Balat et al.,2010 and reported the world wide biodiesel production volumes which is reported in Table no 1.

Dinesh et al.,2016 has explored the need of renewable energy sources for present fuel scenario. The Bio-fuels looks attractive and inviting source in this situation. Bio-diesel as a fuel of this category are more environmental benefits as a cleaner fuel and reduces emissions by $85 \%$ compare to the petrol-diesel. Combustion of bio-diesel as a fuel in diesel engine is more proper than gasoline and diesel with less emission of carbon monoxide, particulate matter and toxic chemicals. At present, two types of commercially available biofuels, one amongst them is from high oil content food crops such as Soybeans, Sunflower oil, Palm oil etc, where the oil is extracted and converted to biodiesel. While the latter is derived from high sugar content crops like sugarcane, where the sugar extracted, which is then converted to bioethanol (Ding et al.). Considering the major sources like vegetable oil, animal fat including algal sources the biofuels are classified to following types. From consumable plant materials first- generation bio-fuels derived, raised many issues like food versus fuel debate. And moreover edible oils are more expensive than nonedible oils which will not be economical if been practiced.
In this scenario non-edible crops have come up as alternative resources as second generation biofuels. Fuels of first generation are from edible oils like soybean, sunflower seeds or oil palm, corn, sugar cane etc. whereas second generation fuels are from non-edible oils. Forestry waste, wheat stalk etc. are considered as resources of secondgeneration biofuel. Second-generation biofuels of many other types are under development such as biomethanol, biohydrogen etc. Castrol Babassu, Jatropha Curcas, Madhuca Indica, Pongamia pinnata, Cotton seed Karanja and Soapnut seed are some of the oils that comes under this category. Third generation fuels are from microorganisms. Third-generation biofuel, Oilgae called also as Algae fuel, a biofuel from algae and fish oil, oil obtained from slaughter house, and feather fat oil etc are addressed as a source of biofuel in this category. (Nada et al., 2011, S.P.Singh et al., 2010. Abdoli et al., 2014).

\section{Free Fatty Acid (FFA) profile of various sources used for biodiesel production:}

The present section attempts to analyse the typical FFA profile for the commonly used feed stock for biodiesel production in Table no2. Investigations conducted by Canakci et al.,(2001) indicated that if the FFA content in oil is greater than $3 \%$, then the transesterification reaction will not occur. Therefore, the setting of proper limit of FFA should be carefully done. Most of the authors sets FFA limits as $2 \%$ for all transesterification experiments for better yields. The reduction of FFA could be done selectively by the selection of proper catalyst. Several authors have reported various catalyst which includes heterogeneous base catalyst like $\mathrm{NaOH} / \mathrm{Al}_{2} \mathrm{O}_{3}$ for the biodiesel production form very high FFA feedstock like Palm oil Yun et al.,(2011), $\mathrm{NaOH}$ for biodiesel production from Jatropha and Castrol oil (Aldo et al.,2012), Trifluoro methanesulfonic acid (TfOH) for the synthesis of biodiesel from Crude Palm Oil (Mohd et al.,(2011), Chomosulfunic acid for biodiesel production from Low Grade Crude Palm Oil (LGCPO) during which the FFA reduced from $7 \%$ to less than $1 \%$. Hayyan et al., (2010) used an super acid as an effective catalyst for production of biodiesel from LGCPO and FFA of feedstock was effectively reduced from $8.3 \%$ to less than $0.5 \%$. The high FFA content in the feed stock has proven to yield soap formation, if excess alkali catalyzed is used for transesterifcation process which further lowers the biodiesel yield.

Table 1:-The worldwide Volume of biodiesel production in few countries. (Ref:Balat et al., 2010)

\begin{tabular}{|c|c|c|}
\hline Country & $\begin{array}{c}\text { Potential } \\
\text { Volume } \\
\text { (MI) }\end{array}$ & $\begin{array}{c}\text { Production } \\
\text { cost } \\
\text { (US\$ per } \\
\text { liter) }\end{array}$ \\
\hline Philippines & 1234 & 0.53 \\
\hline Indonesia & 7595 & 0.49 \\
\hline $\begin{array}{c}\text { Netherland } \\
\text { s }\end{array}$ & 2496 & 0.75 \\
\hline Brazil & 2567 & 0.62 \\
\hline Malaysia & 14,540 & 0.53 \\
\hline
\end{tabular}




\begin{tabular}{|c|c|c|}
\hline Germany & 2024 & 0.79 \\
\hline USA & 3212 & 0.70 \\
\hline Belgium & 1213 & 0.78 \\
\hline Spain & 1073 & 1.71 \\
\hline Argentina & 5255 & 0.62 \\
\hline
\end{tabular}

\section{Sludge Palm oil waste an effective feed stock for Biodiesel Preparation and its current scenerio}

The Palm Oil Research Institute of Malaysia (PORIM) since 1988, has taken an effective initiative to look at the possibilities of converting palm oil and its derivatives into biofuels. The one such outcome which took deep insight was the production and utilization of methyl ester of palm oil towards the diesel substitute. The methyl ester of was then called as Palm Oil Diesel (POD) (Kalam et al 2002). Palm oil is generally extracted from mesocarp (fruit part), is used for edible purposes. Oil palms are originally from West Africa country, but can grow vigorously wherever heat and rainfall are adequate. Palm oil presently is grown throughout the regions of North America, South America, Asia and Africa. Indonesia and Malaysian countries account for about $85 \%$ of globally produced palm oil exports. The oil Palm possess the scientific name as Elaeis guineensis, is amongst one of the well-known and universally accepted fuel resources. Compared to other crop varieties palm oil is very productive and economical. It is seen from the history that the origin of Oil Palm is originated in the tropical rain forest region of Western part of Africa. Palm fruits are processed in mills for the edible usage and is been practiced for thousands of years in Africa country. The countries like US and from there the Eastern part countries got the palm fruits during $14^{\text {th }}$ to $17^{\text {th }}$ centuries. The cost of production is low compared to other crops which also offers far greater yield. The yield of palm oil is comparatively more per hectare than any other crops. Palm oil yields around 20-35 tonnes of fresh fruit per hectare. The average production per Palm tree is about 12 to 15 fruit bunches per year, each weighing is about 25 and $30 \mathrm{kgs}$. Utilization of waste sludge Palm oil (which exists as semisolid) for biofuel production will solve the environmental issues from the disposal point of view which will reduce the crisis of environmental hazardous, rather than being untreated. Other than that, land filling the sludge solid is an expensive and ineffective disposal method Gopal et al., (2009).

\section{Different Oil Palm varieties and biomass}

The different forms of oil palm are available in the market. To name few are Crude Palm Oil (CPO), Kernel Palm Oil of crude form, Crude Palmolein of crude form, and Oil Palm. By-products of the oil extraction process is mainly dependent on discharge of palm oil mill effluent (POME) that consists of Oil Palm trunks and fronds, fruit bunches that are empty, and PK (palm kernel) shells, less fibrous material like palm kernel cake and liquid palm.. These byproducts have to be treated as hazardous. (Khairiah,et al., 2006). High solid wastes of Palm Oil Mill Effluent (POME) are converted to valuable products such as organic fertilizers and feed stocks. POME can be digested by arthworms producing valuable products like vermi-compost which is a useful product that is enriched with nutrients that can be used as fertilizer in palm cultivation plantations. (Khairiah, et al., 2006). There are vast amounts of low grade oils from palm oil industry that can be converted to biodiesel such as sludge palm oil (SPO), a by-product obtained during its milling process. The use of SPO can lower the cost of biodiesel production significantly, which makes SPO a highly potential and alternative feedstock for biodiesel production. SPO usually contains high amounts of free fatty acid (FFA) that cannot be converted to esters of fatty acid by the proper treatment with the acidic catalysts (Hayyan et al 2010).

The biomass together with trunks and fronds could be employed as fertilizers for variety of crops. Empty fruit bunches could also be mixed with polyurethane ester to prepare fiber boards of medium density, exhibiting better water resistance and higher impact strength. Waste sludge oil Palm possess three important components, i.e. mixture of oil, water and solid sludge. In clarifying station, the oil Palm sludge is separated into oil and sludge. An approximate average composition of oil Palm sludge might be $19 \%$ of water, $72 \%$ of oil, and $9 \%$ of non oil solid. Sludge Palm oil is actually a mixture of about 92 to.95\% oil, $4-5 \%$ oil soluble. Also it contains about $0.5 \%$ water, water soluble and solids, Nurulhuda et al., (2009). The sludge is usually referred as the liquid colloidal discharge. This is the residue left from the purification of the crude Palm oil (CPO) and includes various suspended solids, dirt, liquid, and cellulosic material from the fruits. Most of the modern Palm oil mills have adopted the decanter to function as clarifier in order to reduce the solids present in the waste water before disposing them. Using the system of decanter-drier, a pasty solid byproduct is recovered as decanter cake. The average production of POME is 13.60 ton/ha and about 0.67 ton of POME is generated for every ton of fresh fruit bunch processed. It is found to be rich in minerals and therefore suitable organic fertilizer in crop cultivation Alimonetal.,(2007).

The typical physico chemical characteristics of Acidic Grade Crude Palm Oil (AGCPO) and Low Grade Crude Palm Oil (LGCPO) obtained from the Malaysian palm oil industry have been reported in the Table No 3. The qualitative analysis of Sludge Palm Oil waste was determined by the authors based on various parameters such as free fatty acids, iodine value, Saponification value and peroxide value. As the sludge exists in semi solid phase at room temperature most of the literature suggests preheating the sludge in order to reduce the viscosity, moisture content and to break down of FFA to an considerable extent. Hossain et al.,(2010), (Adeeb Hayyan 2014,2010,2014, Mohd Ali Hashim et al.,2011). During the process of pre-heating the flow properties of waste Sludge waste changes from semisolid phase to liquid phase. Generally, the pre-heating is performed at $70^{\circ} \mathrm{c}$ to $80^{\circ} \mathrm{c}$ for about $30 \mathrm{~min}$ to $60 \mathrm{~min}$, depending on the crude /waste sludge characteristics on hot plate as adopted by Aldo et al., (2012). 
However, form biodiesel production point of view the palm oil effluent or waste sludge is reported as an effective feed stock for the Biodiesel production. Authors have reported the treatment of Acidic grade crude palm oil/Low grade crude palm oil and also for that palm oil waste sludge which posses' high free fatty acid by using Sulfuric acid and $p$ Toulenesulfonic acid which are the common homogenous acid used. The common heterogeneous acids are Ferric Sulphate, Solid Brønsted acid of amorphous carbon bearing $\mathrm{SO}_{3} \mathrm{H}, \mathrm{COOH}$ and phenolic $\mathrm{OH}$ groups are also used. The report also suggests the utilization of homogenous acids like Ethanesulfonic acid, Chromosulfuric acid Trifluoromethanesulfonic acid (Super acid) and Perchloric acid for pre-treatment of such high FFA palm waste sludges (Adeeb Hayyan 2014, Mohd Ali Hashim et al.,2011. The most important palm oil fuel properties along its composition are mentioned in Table no 4. It can be noticed that The energy yeild of palm oil has been reported to be higher than any other oils (Figure no 1 and Table no 5). Hence palm oil is considred to be as effective biodiesel feedstock. This implies that the sludge obtained from palm oil effluent mill can also be effective feedstock for biodiesel production as the sludge also contain small quantatity of palm oil. A Hayyan et al.,(2013) has observed that the FFA for low grade crude of palm oil as high in which Palmitic and oleic seems to be higher percentage which shows the presence of large proportions saturated fatty acid and due to which the LGCPO was repeated to be less prone to oxidation which yields high cetane number. Aldo et al.,(2012). Hence it can be concluded that the sludge palm oil and its sludge waste can be utilized to produce biodiesel which is having good heat of combustion value. Man Kee et al.,(2009) has reported and compared the ratio of output energy to input energy for various oils (as mentioned in Table no 5. The similar author reported that the palm oil posses high yield per unit Hectare of palm cultivation.

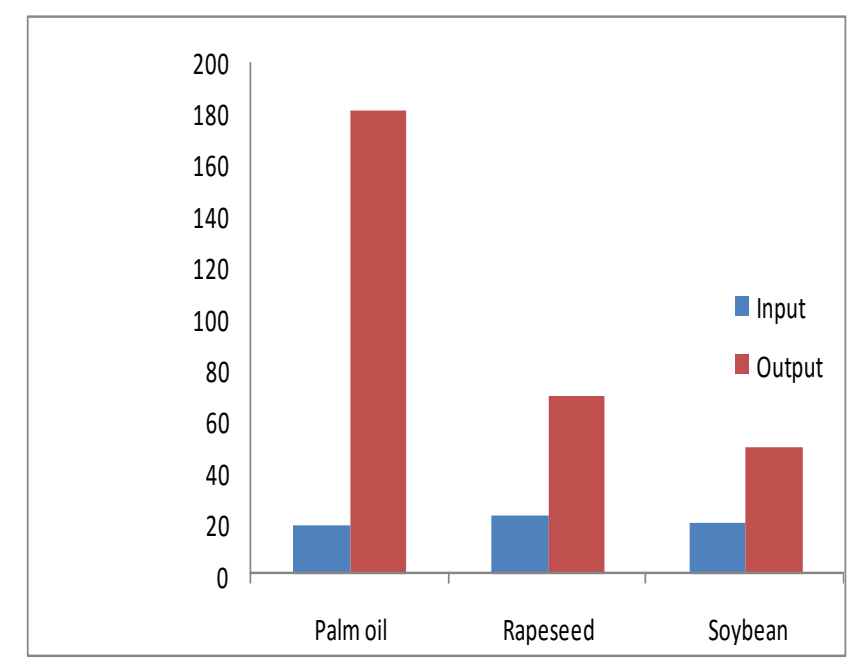

Fig 1: - Energy yield comparison of palm oil vs others oil

Used commonly for biodiesel production.

The literature indicates that the unsaturated fatty acids like Oleic, Linoleic, and Palmitic contributes towards the good calorific value, as the carbon chain length of biodiesel produced matches with that of these fatty acids. Aldo et al.,(2012). As mentioned in the Table no:-2 the profile of FFA suggests for palm oil indicates the suitability for biodiesel production. Typically, the unsaturated fatty acids like Palmatic, Oleic, Linolenic contains double bonds and triple bonds which are complex to breakdown and also possess high FFA value if they are present in more percentages. Hence Acidic catalyst are used, which helps in the breaking down of double and Triple bonds, thereby reducing the higher FFA values in the feed stock. Jatropha oil majorly comprises of Linoleic acid $43 \%$, oleic acid $35 \%$ and Palmitic acid is $15 \%$ and the Castrol oil comprises $4.6 \%$ Linoleic acid, $3.98 \%$ of oleic acid and $1.31 \%$ of Palmitic acid. Therefore, the value of heat of combustion from the biodiesel produced from Jatropha and Castrol oil are found to be $43 \mathrm{MJ} / \mathrm{Kg}$ and $39 \mathrm{MJ} / \mathrm{Kg}$ respectively. Kazi et.al (2010) reported calorific value of Jatropa biodiesel as 41 $\mathrm{MJ} / \mathrm{kg}$. The general heat of combustion of petro-diesel is 47 $\mathrm{MJ} / \mathrm{kg}$. The calorific values which is teremed as heating value of biodiesel is generally $12 \%$ less than petro-diesel according to. Based on absolute values, the neutralized palm biodiesel has observed to possess same range of calorific value as that of castor oil, whereas Singh et al., (2010) reported the heating value of palm biodiesel as $33(\mathrm{MJ} / \mathrm{kg})$. The calorific value is strongly attributed to the fatty acids profile of feed stock used for biodiesel production. Palm oil is predominantly made of palmitic acid, a saturated fatty acid that that is associated with higher energy content than unsaturated acids like Palmitolileic acid, Arachidice acid, Stearic acid, Lauric acid and Myristic acid. Neutralisation of palm oil have reported to improves heats of combustion of palm biodiesel from 33.5 to $39 \mathrm{MJ} / \mathrm{kg}$ (Table 4).

The attempt has been made to consolidate the various sources which are used for biodiesel production as reported in Table no 6 along with the catalyst used, reaction condition, its major fuel properties like density, viscocity, flash point. 
Table: -2 Comparison of fatty acid profile of different sources of oil for biodiesel production. Ref: -Gaurav etal., (2013)*,Aldo etal.,(2012)**, Adeeb Hayyan et al.,( 2013)***, Abdoli et al.,(2014) ****

\begin{tabular}{|c|c|c|c|c|c|c|c|c|c|}
\hline $\begin{array}{l}\text { Fatty } \\
\text { Acid }\end{array}$ & $\begin{array}{l}\text { Structur } \\
\text { e }\end{array}$ & $\begin{array}{l}\text { \% for } \\
\text { Jatrop } \\
\text { ha } \\
\text { 0il * }\end{array}$ & $\begin{array}{l}\% \text { for } \\
\text { Pongami } \\
\text { a Oil ** }\end{array}$ & $\begin{array}{l}\% \text { for } \\
\text { Castor } \\
\text { Oil** }\end{array}$ & $\begin{array}{l}\% \text { for } \\
\text { Soybea } \\
\text { n oil } * *\end{array}$ & $\begin{array}{l}\% \text { for } \\
\text { Palm } \\
\text { oil } * *\end{array}$ & $\begin{array}{l}\text { \% for } \\
\text { LGCP } \\
\text { O } \\
* * *\end{array}$ & $\begin{array}{l}\text { \% for } \\
\text { FAME } \\
\text { of } \\
\text { WOS* }\end{array}$ & $\begin{array}{l}\text { \% for } \\
\text { Poultry } \\
\text { fat } * * * *\end{array}$ \\
\hline $\begin{array}{l}\text { Lauric } \\
\text { acid }\end{array}$ & $\mathrm{C} 12$ & - & - & NR & NR & NR & $\begin{array}{c}0.394 \pm 0 \\
.02\end{array}$ & NR & NR \\
\hline $\begin{array}{l}\text { Myristic } \\
\text { acid }\end{array}$ & C14 & $\begin{array}{c}0-0.1 \\
\text { ND* }^{*}\end{array}$ & - & Traces & 6.4 & NR & $\begin{array}{c}1.04 \pm 0 \\
03\end{array}$ & NR & $3 \%$ \\
\hline $\begin{array}{l}\text { Palmitic } \\
\text { acid }\end{array}$ & C16 & $\begin{array}{c}14.1- \\
15.3 \\
15.32 \pm \\
0.07 * *\end{array}$ & 6.8 & 1.31 & 13 & 42.12 & $\begin{array}{c}44.9 \pm 1 \\
92\end{array}$ & 55.1 & $30 \%$ \\
\hline $\begin{array}{l}\text { Palmitoli } \\
\text { leic acid }\end{array}$ & C16:1 & $\begin{array}{c}0-1.3 \\
1.33 \pm 0 \\
.01 * *\end{array}$ & - & Traces & NR & NR & $\begin{array}{c}0.40 \pm 0 \\
02\end{array}$ & NR & NR \\
\hline $\begin{array}{l}\text { Stearic } \\
\text { acid }\end{array}$ & C18 & $\begin{array}{c}3.7- \\
9.8 \\
4.06 \pm 0 \\
.02 * *\end{array}$ & 6.7 & - & $4 \%$ & NR & $\begin{array}{c}3.90 \pm 0 \\
5\end{array}$ & NR & $22 \%$ \\
\hline $\begin{array}{l}\text { Oleic } \\
\text { acid }\end{array}$ & C18:1 & $\begin{array}{c}34.3- \\
45.8 \\
35.38 \pm \\
0.20 * *\end{array}$ & 51 & 3.98 & 13 & 40.31 & $\begin{array}{l}39.70 \\
\pm 2.47\end{array}$ & 37.9 & $8.1 \%$ \\
\hline $\begin{array}{l}\text { Linoleni } \\
\text { c acid }\end{array}$ & C18:3 & $\begin{array}{c}0-0.3 \\
43.34 \pm \\
0.21 \\
* *\end{array}$ & 6.3 & 4.6 & 55 & 10.49 & $\begin{array}{c}9.09 \pm 1 \\
0\end{array}$ & 6.4 & $25 \%$ \\
\hline $\begin{array}{l}\text { Arachidi } \\
\text { ce acid }\end{array}$ & $\mathrm{C} 20$ & $0-0.3$ & 0.8 & NR & NR & NR & $\begin{array}{c}0.34 \pm 0 \\
077\end{array}$ & 0.4 & $7 \%$ \\
\hline
\end{tabular}

Table 3:- Physico chemical Characteristics of AGCPO and LGCPO reported form palm oil processing mill Malaysia .Ref:(Adeeb Hayyan 2014, *A. Hayyan 2013)

\begin{tabular}{|c|c|}
\hline FFA (\%) & $8.8,7.0 \pm 0.30^{*}$ \\
\hline Peroxide value (ml mol/kg) & $7.9,7.5 \pm 0.65^{*}$ \\
\hline Moisture content (\%) & $1.4,1.03 \pm 0.1^{*}$ \\
\hline Iodine value & 52.5 \\
\hline Impurities (\%) & $0.06,0.050 \pm 0.006$ \\
\hline $\begin{array}{c}\text { Saponification } \\
\text { value(mgKOH/goil) }\end{array}$ & $191,198.00 \pm 1.70^{*}$ \\
\hline Ash (\%) & $0.015,0.010 \pm 0.001^{*}$ \\
\hline
\end{tabular}

Table 4:-Oil Palm Fuel Properties (Ref:-Adam et al., (2014)**, * Singh et al., (2010)

\begin{tabular}{|c|c|c|c|c|c|}
\hline Oil & $\begin{array}{c}\text { Composition of } \\
\text { fatty acid }\end{array}$ & $\begin{array}{c}\text { Density/ } \\
\text { g/m3 }\end{array}$ & $\begin{array}{c}\text { Flash } \\
\text { Point } \\
\mathbf{o}^{\mathbf{C}} \mathbf{C}\end{array}$ & $\begin{array}{c}\text { Acid value } \\
\mathbf{m g ~ K O H} / \mathbf{g} \\
\text { oil }\end{array}$ & $\begin{array}{c}\text { HV } \\
\text { (Megha } \\
\text { jouls/kg) }\end{array}$ \\
\hline Palm & $\begin{array}{c}\mathrm{C} 16: 0, \mathrm{C} 18: 0, \mathrm{C} 18 \\
: 1, \mathrm{C} 18: 2\end{array}$ & 0.92 & 267 & 0.2 & $\begin{array}{c}33.5^{*} \\
39^{* *}\end{array}$ \\
\hline
\end{tabular}

Table 5:-Energy yield comparison of palm oil vs others Ref:- (Man Kee et al.,2009)

\begin{tabular}{|c|c|c|c|}
\hline $\begin{array}{c}\text { Energy } \\
\text { ratio }\end{array}$ & $\begin{array}{c}\text { Soyabean } \\
\text { oil }\end{array}$ & $\begin{array}{c}\text { Rapeseed } \\
\text { oil }\end{array}$ & $\begin{array}{c}\text { Oil } \\
\text { palm }\end{array}$ \\
\hline GJ/ha & 2.5 & 3.0 & 9.6 \\
\hline
\end{tabular}




\section{CONCLUSION}

It can be concluded that to meet the current energy requirement which is constantly increasing across the globe the demands i.e. the energy generation has to occur by the utilization of the waste to fuel. Considering the above facts, discussions etc it can be concluded that waste oil like fried oils, waste vegetable cooking oils, waste animal fat from slaughter house including waste sludges generated from the oil processing industries could be cost effective feedstock for the biodiesel production. They are attractive, alternative feedstock for biodiesel production The literature studied to investigate the phsico-chemical properties of especially palm oil sludge from POME is very potentional feedstock for biodiesel production in term of fatty acid composition and peoperties. This not only solves the disposal issues but also contribute to the fuel demands.

Table 6:- Biodiesel from various sources.

\begin{tabular}{|c|c|c|c|c|c|c|c|c|c|}
\hline $\begin{array}{l}\text { Sl. } \\
\text { No }\end{array}$ & $\begin{array}{l}\text { Biodiesel } \\
\text { Feed } \\
\text { stock }\end{array}$ & $\begin{array}{l}\text { Flash } \\
\text { point } \\
\left({ }^{\circ} \mathrm{C}\right)\end{array}$ & $\begin{array}{l}\text { Density } \\
\left(\mathrm{Kg} / \mathbf{m}^{3}\right)\end{array}$ & $\begin{array}{l}\text { CV } \\
\text { (MJ/kg } \\
\text { ) }\end{array}$ & $\begin{array}{l}\text { Viscosit } \\
\mathbf{y} \\
(\text { Cst) }\end{array}$ & $\begin{array}{l}\text { Catalyst } \\
\text { Used }\end{array}$ & $\begin{array}{l}\text { Temp } \\
\text { of } \\
\text { Reactio } \\
\text { n } \\
\left({ }^{\circ} \mathrm{C}\right)\end{array}$ & $\begin{array}{l}\text { Methan } \\
\text { ol to oil } \\
\text { ratio }\end{array}$ & Ref \\
\hline 1. & Jatropha & 166 & $\begin{array}{l}871 \\
620 *\end{array}$ & $\begin{array}{l}42 \\
41 *\end{array}$ & $\begin{array}{l}5.5 \\
5.34 *\end{array}$ & $\begin{array}{l}\mathrm{NaOH} \\
\mathrm{H}_{2} \mathrm{So}_{4}\end{array}$ & $55-60$ & $6: 1$ & $\begin{array}{l}\text { Aldo et.al. } \\
\text { * Kazi et.a.l }\end{array}$ \\
\hline 2. & $\begin{array}{l}\text { Castor } \\
\text { oil }\end{array}$ & 160 & 900 & 30.4 & 10.7 & $\begin{array}{l}\mathrm{NaOH}, \\
\mathrm{H}_{2} \mathrm{So}_{4}\end{array}$ & $55-60$ & $6: 1$ & Aldo et.al. \\
\hline 3. & $\begin{array}{l}\text { Pongami } \\
\text { a }\end{array}$ & $\begin{array}{l}150^{*} \\
156\end{array}$ & $\begin{array}{l}905^{*} \\
874\end{array}$ & $\begin{array}{l}36^{*} \\
29.4\end{array}$ & $\begin{array}{l}8.9^{*} \\
19\end{array}$ & $\begin{array}{l}\mathrm{NaOH}^{*} \\
\mathrm{NaOH}\end{array}$ & $\begin{array}{l}60-65 * \\
50\end{array}$ & $\begin{array}{l}1 \%(\mathrm{w} / \mathrm{w} \\
)^{*} \\
30 \% \\
(\mathrm{v} / \mathrm{v})\end{array}$ & $\begin{array}{l}\text { Gaurav } \\
\text { et.al. } \\
\text { *Naik et.al. }\end{array}$ \\
\hline 4. & $\begin{array}{l}\text { Soy bean } \\
\text { oil }\end{array}$ & NR & NR & NR & $1.9-6^{*}$ & $\begin{array}{l}\mathrm{NaOH}^{*} \\
\mathrm{HCL} \\
\mathrm{H} 2 \mathrm{SO} 4 \\
\mathrm{HNO} 3\end{array}$ & $\begin{array}{l}55^{*} \\
75\end{array}$ & $\begin{array}{l}1: 1^{*} \\
8: 1\end{array}$ & $\begin{array}{l}\text { *Hossain } \\
\text { et.al. } \\
\text { Chia et.al. }\end{array}$ \\
\hline 5. & Fish oil & 147 & $920 * *$ & 39.5 & $6.2 *$ & NR & NR & NR & $\begin{array}{l}\text { Savariraj } \\
\text { et.al }\end{array}$ \\
\hline 6. & $\begin{array}{l}\text { Coconut } \\
\text { oil }\end{array}$ & 85 & 825 & 45 & 3.4 & NR & NR & NR & $\begin{array}{l}\text { Liaquat, } \\
\text { et.al }\end{array}$ \\
\hline 7. & $\begin{array}{l}\text { Waste oil } \\
\text { sludge }\end{array}$ & NR & NR & NR & NR & $\begin{array}{l}\mathrm{H}_{2} \mathrm{So}_{4} \\
\text { and } \\
\mathrm{Fe}_{2}\left(\mathrm{So}_{4}\right)_{3}\end{array}$ & $60-100$ & $5: 30$ & $\begin{array}{l}\text { Guanaand } \\
\text { et.al }\end{array}$ \\
\hline 8. & $\begin{array}{c}\text { Crude } \\
\text { Palm oil }\end{array}$ & 185 & 859 & 39.5 & 4.6 & $\begin{array}{l}\text { Chromo } \\
\text { Sulfuric } \\
\text { acid }\end{array}$ & 60 & $10: 1$ & $\begin{array}{l}\text { Hayyan } \\
\text { et.al( } 2013\end{array}$ \\
\hline 9 & LGCPO & NR & NR & NR & NR & $\begin{array}{c}\text { Perchlori } \\
\text { c acid } \\
\text { and } \mathrm{KOH} \\
\text { NNDEA } \\
\text { +pTSA }\end{array}$ & $\begin{array}{l}60 \\
60\end{array}$ & $\begin{array}{c}10: 1 \\
8: 1\end{array}$ & $\begin{array}{l}\text { Hayyan } \\
\text { et.al(2014) } \\
\text { Hayyan } \\
\text { et.al(2013) }\end{array}$ \\
\hline 10 & $\begin{array}{c}\text { Waste } \\
\text { sludge } \\
\text { oil }\end{array}$ & NR & NR & NR & NR & $\begin{array}{l}\mathrm{Fe} 2(\mathrm{SO} 4) \\
3 \\
\mathrm{FeCl} 3 \\
\mathrm{FeSO} 4 \\
\mathrm{H} 2 \mathrm{SO} 4\end{array}$ & 60 & $10: 1$ & $\begin{array}{l}\text { Guoqing } \\
\text { et.al(2012) }\end{array}$ \\
\hline 11 & $\begin{array}{c}\text { Feather } \\
\text { fat oil }\end{array}$ & NR & NR & NR & NR & $\begin{array}{l}\mathrm{H} 2 \mathrm{SO} 4 \\
\mathrm{KOH}\end{array}$ & $60-80$ & $\begin{array}{c}4: 1 \text { to } \\
8: 1\end{array}$ & $\begin{array}{l}\text { Abdoli } \\
\text { et.al(2014) }\end{array}$ \\
\hline 12 & $\begin{array}{c}\text { Palm } \\
\text { Biodiesel }\end{array}$ & 185 & 859 & 39 & 4.66 & -- & -- & -- & $\begin{array}{l}\text { Soni } \\
\text { et.al(2008) }\end{array}$ \\
\hline
\end{tabular}




\section{REFERENCES}

[1] Abdoli, M.A. Mohamadi, F.Ghobadian, Fayyazi,2014,'Effective parameters on biodiesel production from featherfat oil as a cost effective feed stock" Int.J. Envrion. Res., 8(1):139-148,Winter , ISSN: 1735-686,2014.

[2] Adam F.Lee, Jamees A. Bennett, Jinesh. C. Manayil and Karen Wilson, 2014 "Heterogenous catalysis for sustainable biodiesel production via esterification and transesterification", Review Article, Chem. Soc. Rev., 43, 7887-7916.

[3] Aldo Okullo, A.K.Temu, P.Ogwok, J.W. Ntalikawa, 2012 "Physico-Chemical properties of biodiesel from Jatropa and castor oil" International Journal of Renewable Energy Research Vol.2, No.1.

[4] Angel Sanchez, Rocio Macerias,Angeles Cancela, Monica Rodriguez, 2012 "Influnence of n-Hexane on in situ Transesterification of Marine Macroalge" Energies, 243-257; doi:10.3390/en5020243ISSN 1996-1073.

[5] A.Anitha and S.S. Dawn, 2010 "Performance Charctersticics of Biodiesel produced from Waste ground nut oil using supported heteropolyacid" Internation Journal, of Chemical Engineering and Applications, Vol. 1, No. 3.

[6] A.R.Alimon and W.M.Wan Zahari "Recent advances in utilization of oil palm byproduct as animal feed" Department of animal science university Putra, Malaysia, 43400 Serdang Selangor

[7] I.M. Atadashi, M.K. Aroua, A.Abdul Aziz, 2011 "Biodiesel separation and purification A review" Elsevier, Renewable energy,36, 437e443.

[8] Balat.M. Balat.H"Progress in biodiesel processing”, 2010, Applied energy, 87 (6):1815e35

[9] Canakci. Mustafa and Jon H, Van Gerpen, 2001 "The performance and emission of a diesel engine fueled with biodiesel from from yellow grease and soyabean oil" The society of Engineering in Agriculture Food and Biological Systems, 1-17.

[10] Chia-Hung Su, 2013, "Recoverable and reusable hydrochloric acid used as a homogeneous catalyst for biodiesel production", Elsevier, Applied Energy,104 ,503-509.

[11] Dinesh.S. Nichat , D.B.Shelke "Bio-Diesel Production from Waste Cooking Oil Via Acids Catalysis and Its Blends with Diesel", 2016, International Journal of Current Engineering and Technology, E-ISSN 2277 - 4106, P-ISSN 2347 5161.

[12] Ding.Z., Das. P. "Optimization of the Temperature and reaction duration of one step transesterification" Department of environmental science and engineering, School of Engineering, National university of Singapore, 21, Lower Kent Ridge road, Singapore 119077.

[13] Divya Bajpai,V.K.Tyagi (2006) "Review on Biodiesel sources production consumption properties and its benefits", Journal of Olo Science, Vol 55, No 10487 to 50 .
[14] Gopal Dashiny "Oil Recovery From Palm Oil Solid Wastes" 2009, Faculty of Chemical and Natural Resource Engineering, University Malaysia Pahang.

[15] Gaurav Dwivedi and M.P. Sharma, 2013 "Performance Evaluation of Diesel Engine Using Biodiesel from Pongamia Oil". International Journel of Renewable Energy Research,3(2).1-6.

[16] Guoqing Guana and Katsuki Kusakabe, 2012, "Biodiesel Production from Waste Oily Sludge By Acid-Catalyzed Esterification" International Journal ofbiomass \& renewables, 1, 1- 5 .

[17] Guanaand Guoqing KatsukiKusakabe, 2008 "Biodiesel Production from Waste Oily Sludge By Acid-Catalyzed Esterification".

[18] Hayyan. M.Z. ALam, M.E.S. Mirghani, N.A. Kabbashi, N.I.N. M. Hakimi, Y.M. Siran and S. Tahiruddin,, 2010 " Production of Biodiesel from Sludge Palm Oil by Esterification Process" Journal of Energy and Power Engineering, ISSN 1934-8975, USA, Volume 4, No.1 (Serial No.26).

[19] Hayyan. A, F.S. Mijalli, M.A. Hashim, M. Hayyan, I.M. Al Nashef ,2013 "Conversion of free fatty acids in low grade crude palm oil to methyl esters for Biodiesel production using chromosulfuric acid". Bulgerian Chemical Communications.45 (3) 394 399.

[20] A. Hayyana, Mohd Ali Hashima, Maan Hayyana, Farouq S. Mjalli, Inas M. ANashefc, 2013 “A novel ammonium based eutectic solvent for the treatment of free fatty acid and synthesis of biodiesel fuel" Elesvier, Industrial Crops and Products 46 (2013) 392- 398.

[21] A. Hayyan, Mohd Ali Hashim, Maan Hayyan, Khor Gui Qing 2014 "Biodiesel Production from Acidic Crude Palm Oil Using Perchloric Acid" Elesvier, Energy Procedia 612745 - 2749.

[22] Kazi MostafijurRahman, Mohammad Mashud, Roknuzzaman and Asadullah Al Gali,2010 "Biodiesel from Jatropha Oil as an Alternative Fuel for Diesel Engine" International Journal of Mechanical and Mechatronics Engineering, Vol:10 No:03.

[23] M.A. Kalam,H.H. Masjuki 2002 "Biodiesel from palmoil an analysis of its properties and potential", Pergamon Biomass and Bioenergy 23, 471 - 479.

[24] A.M.Liaquat, H.H.Masjuki, M.A.Kalam, I.M.Rizwanul Fattah, M.A.Hazrat, M. Varman, M. Mofijur, M. Shahabuddin, 2013, "Effect of coconut biodiesel blended fuels on engine performance and emission characteristics" Elsevier, Procedia Engineering 56, 583-590.

[25] Man Kee Lam, Kok Tat Tan, Keat Teong Lee, Abdul Rehaman Mohammad, 2009 " Malaysian Palm Oil, Surviving the food vs Fuel, dispute for a sustainable future",Elsevier, Renewable and Sustainable Energy reviews, 13 1456-1464.

[26] Muhammad Rizuan Bin Musa, Faculty of Mechanical Engineering Universiti Malaysia Pahang, 2010 "Characteristic of Palm Oil Methyl Ester as Alternative Fuel". 
[27] Mohd Ali Hashim, AdeebHayyan ,Farouq.S, Mjallib, Maan Hayan.(2011) "Pre-Treatment of Crude PalmOil Using Super Acid for Biodiesel Production". Intrenational Journal of Sustainable water and environmental Syatem. Volume 3, No. 1 (2011) 1924.

[28] Mohd Ali Hashim, AdeebHayyan ,Farouq.S, Mjallib, Maan Hayyan.(2011) "Pre-Treatment of Crude PalmOil Using Super Acid for Biodiesel Production". International Journal of Sustainable Water and Environmental Systems. Volume 3, No. 1 (2011) 1924.

[29] Naik P. L. and D. C. Katpatal, 2013 "Performance Analysis of CI Engine using Pongamia Pinnata (Karanja) Biodiesel as an Alternative Fuel", International Journal of Science and Research (IJSR), Volume 2 Issue 8, August 2013, 445-450. ISSN: 2319-7064.

[30] Nurulhuda Binti Kasim, 2009 "Seperation technique of crude palm oil at clarification area viaoptimum parameters", Faculty of Chemical and Natural resource Engineering, Universiti Malaysia, Pahang.

[31] Nada E.M. ElSolh "The Manufacture of Biodiesel from the used vegetable oil" 2011, Kassel, Departments of Electrical and Mechanical Engineering Degree Program: Renewable Energy and Energy Efficiency for the Middle East North Africa Region- Cooperation between Kassel and Cairo Universities.

[32] S.P. Singh, Dipti Singh (2010) "Biodiesel production through the use of different sources and characterization of oils and their esters as the substitute of diesel A review" Elsevier, Renewable and Sustainable Energy Reviews 14 200-216.

[33] 33.Savariraj, T, Ganapathy, C. G, Saravanan, 2013 "Performance, emission and combustion characteristics of fish-oil biodiesel engine", European Journal of Applied Engineering and Scientific Research, 2 (3), 26-32, ISSN: 2278 - 0041.

[34] Soni S.Wirawan, Armansyah H. Tambunan, Martin Djamin, Hiroshi Nabetani, 2008 "The Effect of Palm Biodiesel Fuel on the Performance and Emission of the Automotive Diesel Engine" Agricultural Engineering, International, the CIGR Ejournal. Manuscript EE 07 005., Vol. X.

[35] Yun Hintafiq- Yap, Nurulfitriyah Abdullah and Mahiranbasri, 2011 "Biodiesel production via Transesterificationof Palm oil using $\mathrm{NaOH} / \mathrm{AL}_{2} \mathrm{O}_{3}$ Catalysts" Sains Malaysiana , 40(6)(2011): 587-594. 